\title{
Learning English as a Foreign Language through the Listening
}

\section{in Mute Approach}

\author{
Coffi Martinien Zounhin Toboula ${ }^{{ }^{*}}$ \\ ${ }^{1}$ English department, University of Abomey-Calavi (UAC), Benin \\ * Coffi Martinien Zounhin Toboula, E-mail: marcomfr2002@yahoo.fr
}

Received: May 10, 2017

Accepted: May 23, 2017

Online Published: June 5, 2017

doi:10.22158/selt.v5n3p369

URL: http://dx.doi.org/10.22158/selt.v5n3p369

\begin{abstract}
One of the major problems faced by English as a Foreign Language (EFL) learners is the difficulty of decoding words and their meanings. While some are very early discouraged by the large amount of words to know before having a good command of this language, others struggle to progress in learning it because of the complexity of some words due to the multiplicity of their meanings. To overcome this problem, the author of this paper, after several years of research, tried to set up the listening in mute (Note 1) (low volume listening or soft listening) approach which refers to the action of the subconscious that has the capability of assimilating the language instead of the learner ((his or her) (Note 2) conscious mind) while the latter is sleeping in an environment where the English language is spoken in a low voice by native speakers.

Therefore, to examine the effectiveness of this approach, seven Beninese intermediate EFL learners were voluntarily recruited from three English Language Clubs (Note 3). It was recommended to each of them to take the habit of listening to a radio with a reduced volume in a low voice tuned to a channel broadcasting English programs before going to bed at night. The results were very impressive. Through individual interviews and focus groups, participants revealed that their six-month experience in these programs has helped them develop many skills such as listening, meaning-decoding and pronunciation.
\end{abstract}

\section{Keywords}

EFL learners, listening in mute, subconscious, native speakers

\section{Introduction}

The present study attempts to highlight the positive action of the subconscious in language learning. Through a series of experiments, it brings out the way this action is operated without the knowledge of the individual and suggests it for foreign language learning through the concept of listening in mute (low volume listening or soft listening). 


\subsection{Historical Background}

Generally, the process of second or foreign language learning like English is not the same as the one used by the child. Simply put, the mechanism of the L1 acquisition does not always mirror the one of the L2, which makes foreign language learning more difficult than our native language. The major problems faced by foreign language learners are related to the learning approach they use. To have a good command of their target language, they need to adopt a learning strategy that could approximate the one they used instinctively to learn their own mother tongue. As shown by a lot of research, the language acquisition in the child begins from the day of his/her conception. Everything goes through the vibrations she/he receives through his/her mother. Since the first week of his/her conception until the day of his/her birth, the child perceives everything that happens around his/her mother through his/her subconscious (Note 4). At this stage of life, the human being is guided merely by his/her sub-consciousness (that is to say, the conscience asleep). One will later on talk of consciousness (Note 5 ) with him/her only when she/he reaches a certain maturity generally after the age of seven.

However, "The role of conscious and unconscious processes in second language learning is one of the problems under dispute in applied linguistics" (Jin, 2011, p. 126). As contended by Schmidt (1990) (cited in Jin, 2011, p. 126), "the notion of consciousness is both useful and possibly necessary in second language learning". Yet, it is noteworthy to mention that "Conscious processes are important in second language learning, but unconscious processes should not be neglected in language comprehension and production, both of which contribute to second language learning" (Ibid). Similarly, Studies of classroom interaction in language classes at primary level show that pupils spend a large part of their time listening. Most teachers lay emphasis on exposure to a rich linguistic input and favour indirect subconscious learning... (Beaucamp, 2006, pp. 61-62).

The human being during his/her earliest childhood acquires intuitively any language including his/her native one. But once she/he reaches the age of reason, she/he seems to lose that faculty which however still remains innate in him/her. In fact, the acquisition of any language is done through a subconscious process though the learning occurs most of the time at the state of consciousness. Therefore, the conscious mind intervenes only to judge, analyze and assess the development or the progress of this process. The consciousness can also help the subconscious to decode a language. In other words, it can allow the identification of two different languages such as French and English and help to appreciate the level of control achieved in one or the other. In short, to register the new information in our permanent memory, it is necessary that we learn to reach our subconscious directly, bypassing the filter of the conscious mind (Carpenter, 2004).

A lot of research has shown that "the teaching of a foreign language at school gives pride of place to proficiencies under the oral code and understanding in particular" (Beaucamp, 2006, p. 53) (Note 6). However, very few of EFL learners manage to develop their oral communication ability regarding their target language. To make up for this problem, it is vital that "the teacher favors the exposure of his/her learners in a rich input by promoting the subconscious learning of their target language" (Ibid). This 
requires significant use of the outer part of the ear canal and high exposure to the target language in any way to release among EFL learners a learning through impregnation that emphasizes empirical acquisition (Beaucamp, 2006, p. 54).

The present study through the listening in mute approach it addresses aims then to provide second or foreign language learners with a new learning strategy that could help them have a good command of their target language. Generating from this purpose, the present study attempts to answer the following questions:

- Is there any relationship between the subconscious and language acquisition process?

- To what extent can the listening in mute approach help in foreign language learning?

\subsection{Review of Related Literature}

The notions of language acquisition or subconscious learning (genuine learning) and language learning (conscious learning) as elaborated by Krashen $(1981,1983,1985)$ are not perceived in the same way by linguists. While some agree with Krashen that these two processes are independent others contend that we cannot learn a language without acquiring it. They believe that "learning" can never become “acquisition” (Gregg, 1984, p. 94).

However, as pointed out by Haynes (2005, para. 2), "children acquire language through a subconscious process during which they are unaware of grammatical rules". In other words, they get any language in the same way as they acquire their first language. Therefore, to command a language, learners need to adopt a learning process that mirrors the one used by children. And to get there, they "need a source of natural communication" (Ibid). Since language learning is not communicative but "...the result of direct instruction in the rules of language..., ...it is certainly not an age-appropriate activity for young/adult learners" (Ibid, para. 3). Through the language learning process, learners have "...conscious knowledge of the new language and can talk about that knowledge; they can fill in the blanks on a grammar page" (Ibid). Nevertheless, a lot of research has proved that "knowing grammar rules does not necessarily result in good speaking or writing" (Ibid). As added by Haynes (Ibid), "a student who has memorized the rules of the language may be able to succeed on a standardized test of English language but may not be able to speak or write (it) correctly".

According to André Comte-Sponville (2001, p. 127) (Note 7), the term consciousness is one of the most difficult words to define. As the Bible says and reported by the Universal Declaration of Human Rights - all human beings are born free and equal in dignity and rights. They are endowed with reason and conscience and should act towards one another in a spirit of brotherhood (Note 8)-According to Dict Box (2015), "Conscience is the knowledge that someone is watching; it is the sense of right and wrong".

In the psychological sense of the term, Christian Godin (2004) defines consciousness as "la relation intériorisée immédiate ou médiate qu'un être est capable d'établir avec le monde où il vit ou avec lui-même" (Note 9). In the moral sense, he defines it as "la capacité mentale à porter des jugements de valeur moraux ... sur des actes accomplis par soi ou par autrui" (Note 10). 
Otherwise, as pointed out by the hypnotherapist Carole Fortin (n.d.) (Note 11), "the subconscious is separated from the conscious and has its own operating modes". She contends that "the subconscious perceives, thinks and reacts autonomously" and that "the power of the subconscious mind, at some level, is higher than that of the conscious mind as it constitutes $90 \%$ of our overall functioning". She adds that "the subconscious is essentially programmed" and that it would be "impossible for (it) not to be programmed, because of all the impressions that have already been recorded since the intrauterine period". Therefore, everyone is ineluctably programmed. Carole Fortin (n.d.), in her article "Le fonctionnement du subconscient" also explains that paradoxically, without "any program" the subconscious can do nothing and that it is only the conscience which can provide it with one. In other words, the conscience dictates to the subconscious what to do. The subconscious, according to Fortin (n.d.), "has a relentless logic (like a computer); it both accepts any suggestion or any programs indifferently and implements them blindly" without reasoning because it knows what is best for each individual. Once an idea is accepted by it, it begins to put it into practice; (because) words have a very strong power in the subconscious, (basically) the words we hear and our own inner monologue (Fortin, n.d.). At this level, "the subconscious is a prodigious amplifier; it takes the words literally (at face value)" (Ibid), to transmit them to the conscience as they were received.

Thus, contrary to what a lot of people think, during sleep, the brain is still in action through an interchange mechanism between the conscious and the subconscious. In other words, the conscious tends to make way for the subconscious that has an easier memorization ability.

Many research endeavors about memory have been conducted over the last 50 years. At the end of the $20^{\text {th }}$ century, many studies such as those of the Bulgarian Gregory Lozanov and the French Guy Poursin have shown that the brain (memory especially) has an almost unlimited learning capacity. Professor Lozanov, with his method of learning through the Saturation of the two cerebral hemispheres named "suggestopedia" has showed that if we lift inhibitions (blockages of all kinds such as fears, doubts, feelings of inferiority accumulated throughout life) which are often linked to our unconscious or subconscious, so the memory can be increased tenfold. Lozanov is thus one of the first researchers to develop an effortless language learning technique. Through his method of super learning, Lozanov has discovered that one could "immerse" students in an intermediate state of consciousness (between wakefulness and sleep) while maintaining a sufficient level of vigilance so that they get the courses without the risk of falling asleep.

Similarly, Guy Poursin, by drawing on the phosphenisme technique which was elaborated by Dr. Francis Lefebre, developed a form of school learning support based on light called the luminopédagogie. To address the same issue, the author of the present study has developed the listening in mute approach inspired by the works of the two aforementioned authors.

\subsection{Theoretical Framework of the Study: The Concept of the Listening in Mute}

Have you ever had a sensation of a déjà-vu or "already heard"? Have you ever, as a foreign language learner, felt like knowing a word or phrase that you cannot remember the way you come across it? 
Sometimes, the foreign language learner suddenly sees during a reading or a discussion, the meaning of certain words or expressions never encountered by him/her before but which, however, seem so familiar to him/her. This state of affairs is due to the subconscious which has the ability to fly like a bird and to go in search of knowledge or information.

Everybody is endowed with a consciousness and a subconscious that at first sight give the impression of alternating though they work simultaneously. In other words, even in the conscious state, the subconscious works. With its ability to travel far from the individual in whom it exists, the subconscious mind has the faculty of recording everything in its path. Unlike the consciousness, the subconscious refuses nothing. It accepts everything, whatever its nature. It can go anywhere at any time. In its universe, nothing is too difficult. Everything can be accomplished.

It is a dimension in which pain does not exist. This facilitates the assimilation of information without the knowledge of the individual. Everything that is difficult to do in the consciousness becomes easy in the subconscious. Similarly, everything that is repressed by the consciousness will directly bury itself into the subconscious to return one day or another violently in the consciousness. When the information is buried in an individual's subconscious database, this one has the impression of forgetting it until the day the subconscious decides to send it back to his/her consciousness by allowing him/her this way to remember it again. In the database of the consciousness, everything is done systematically by sorting. The information that would not have been able to survive this sorting will automatically be sent to the subconscious that will keep it as long as possible. In this situation, the buried information could have two different ends. It can be referred back to the consciousness by the subconscious when the individual would find him/herself in a similar situation which would make him/her have memories. It can also be sent into the consciousness through the subconscious after a very long moment of lethargy in it, which gives the individual, who has had time to forget it because of the storage of several pieces of information of this kind, the impression of a déjà vu. This impression can also be caused by another phenomenon; that of the "the sleeping consciousness" in which this research work is particularly interested. While an individual is sleeping, his/her consciousness enters a form of torpor and thus allows his/her subconscious to take over. But the individual can return to the consciousness at any moment by a simple "whiplash" materialized by the end of a sleep cycle, a nightmare, a music, a violent noise, a change of temperature, etc. Once awakened, the individual, in a particular situation, may feel like having already experienced, learned, seen or simply been aware of certain information or situations that she/he is confronted with at this particular point in the time. This is due to the rejection of the information recorded by the subconscious of that individual during one of his/her many periods of sleep in his/her consciousness at the precise moment when the latter is confronted with a similar situation. This also gives the impression of a déjà-vu.

What is interesting in these abilities which every single individual possesses is that, even in the state of sleep, the consciousness remains always on the alert, so awake. While the subconscious takes possession of the individual at $75 \%$, the consciousness remains awake at $25 \%$, which explains why an 
individual in his/her sleep is propelled into a free fall, she/he wakes up before falling. This also explains the fact that one can respond to his/her interlocutor even in a deep sleep. There would, therefore, be some interference between the consciousness and the subconscious. There is a reason to believe that during sleep, there comes a time when the consciousness merges with the subconscious but to varying degrees. In sleep, the consciousness that is largely dominated by the subconscious nevertheless arrives to record a large amount of information without difficulty, which would facilitate the learning of foreign languages. To prove this hypothesis, a series of experiments was carried out on a number of learners of English as a foreign language.

Indeed, seven intermediate EFL learners agreed to take part in the experiment for a period of six months. It was recommended to each of them to take the habit of listening to a radio turned on all night long and tuning it to a channel broadcasting English programs while sleeping. To facilitate the action of the subconscious on their consciousness, it was recommended to them to turn low the volume of their radio set. For the phenomenon of "the sleeping consciousness" to be realized effectively during sleep, it is very important not to make too much noise around oneself; which clearly constitutes a necessary condition for the realization of this experience, lest it disturbs the sleep of others.

\section{Methodology of the Study}

\subsection{The Research Participants}

The seven intermediate EFL learners who volunteered to participate in the study were recruited from three English Language Clubs which "are learning crucibles where English is practised effectively..." (Zounhin, 2017, p. 19). There were four males and three females. Their age ranged from 16 to 27 years old. Four of them ( 3 males and 1 female) were in upper $6^{\text {th }}$ and lower $6^{\text {th }}$ grade (Première and Terminale in the French educational system) and three (1 male and 2 females) were undergraduates. All of them have less than a two month experience of language oriented Extracurricular Activities (ECAs) such as the English Language Clubs they have lately discovered and started participating in, hoping to practise and gain more flexibility as well as fluency in their target language.

\subsection{Research Instruments}

Research Instruments are testing devices or research tools designed to measure a given phenomenon or study and obtain data on a topic of interest from research subjects. To test the hypothesis of the present study, a multiple case study has been adopted. The reason why this research method has been adopted to the present study is that "a multiple case study can allow the researcher to analyze within each setting and across settings while a holistic case study with embedded units only allows her/him to understand one unique/extreme/critical case" (Baxter \& Jack, 2008, p. 550). As pointed out by these researchers, "the evidence created from case study design is considered robust and reliable" (Ibid). Furthermore, Baxter and Jack (2008, p. 548) referring to Yin (2003) contend that "a multiple case study enables the researcher to explore differences within and between cases".

Miles and Huberman (1994, p. 25; cited in Baxter \& Jack, 2008) define a case as, "a phenomenon of 
some sort occurring in a bounded context". They add that it is "in effect, your unit of analysis" (1994, p. 25). Merriam (1998, p. 27) views a case as "an individual, a program, a class or students, a school, or a community". Besides, a case study is an empirical research method and one of the qualitative approach to inquiry. It is "a methodological approach that involves the in-depth exploration of a specific bounded system, utilizing multiple forms of data collection to systemically gather information on how the system operates or functions" (Linda, 2010, p. 1). The case in the present study has to do with the evaluation of an instructional program (the listening in mute approach) which was evaluated on different EFL learners. Through the use of this approach, the present study assesses the positive effect of the subconscious in foreign language acquisition.

For the sake of case study research limitation and to ensure that this study remains reasonable in its scope, only seven Beninese Intermediate EFL learners participated in the survey. Therefore, to examine how the program (case) that is under investigation operates in the different individual students who participated in the experiment, this study that was primarily designed as a single case study turns to a multiple-case one. From there on, it was important to "compare between cases (each participant) and answer a question that seeks to explain a presumed causal link in real-life interventions that are too complex for the present survey" (Yin, 2003; cited in Baxter \& Jack, 2008, p. 547).

To achieve a holistic understanding of the beliefs of the intermediate EFL learners who participated in the experiment about the listening in mute educational program, a variety of ethnographic research techniques have been used. Data were collected through semi-structured interviews and focus groups. Before each interview, the informant was reminded of the aim of the study and the reason why she/he was being interviewed. The scope of the interviews was also kept open and flexible with few interruptions. Informants were usually interviewed in a relatively quiet environment at agreed moments and locations to enable the researcher to get a considerable amount of descriptive data on their own perceptions and understanding of the listening in mute approach. The informal interview questions that were addressed to the informants varied from one respondent to another and were not pre-determined as the semi-structured ones. Both types of interview questions were audio-taped and transcribed verbatim for analysis.

The use of focus groups method as a data collection technique also helps the different procedures used in the present research study to increase the validity of the research findings. When conducting the focus group discussions, each group was kept focused on the issue of their experience of the listening in mute approach. The collection of data from each of the two focus groups lasted from 40 to 60 minutes and those data were transcribed verbatim for analysis. All the participants enjoyed the experiment about this learning approach and were very enthusiastic to talk about their experience. Therefore, no information concerning their identity is provided in the study. Pseudonyms are used to refer to them (See Table 1). 
Table 1. Overview of the Participants in the Individual Interviews and the Focus Groups

\begin{tabular}{|c|c|c|c|c|c|c|}
\hline Group & Name & Gender & Age & School grade & ELC's name & Proficiency level in English \\
\hline \multirow[t]{4}{*}{ One } & Aminata & Female & 21 & $\begin{array}{l}\text { Undergraduate } \\
\text { (First year at the } \\
\text { English } \\
\text { Department) }\end{array}$ & $\begin{array}{l}\text { Titigweti English Club } \\
\text { (Venue: University of Abomey-Calavi, } \\
\text { Benin) }\end{array}$ & Intermediate \\
\hline & Dossou & Male & 20 & Upper $6^{\text {th }}$ & $\begin{array}{l}\text { Afro-Dream English Club } \\
\text { (Venue: CEG Godomey) }\end{array}$ & Intermediate \\
\hline & Cokou & Male & 18 & Lower $6^{\text {th }}$ & $\begin{array}{l}\text { English Community Oasis Club } \\
\text { (Venue: College Martin Luther King of } \\
\text { Cotonou, Benin) }\end{array}$ & Intermediate \\
\hline & Assiba & Female & 16 & Lower $6^{\text {th }}$ & $\begin{array}{l}\text { Afro-Dream English Club } \\
\text { (Venue: CEG Godomey) }\end{array}$ & Pre-intermediate \\
\hline \multirow[t]{3}{*}{ Two } & Codjovi & Male & 19 & Upper $6^{\text {th }}$ & $\begin{array}{l}\text { English Community Oasis Club } \\
\text { (Venue: College Martin Luther King of } \\
\text { Cotonou, Benin) }\end{array}$ & Intermediate \\
\hline & Dossi & Female & 23 & $\begin{array}{l}\text { Undergraduate } \\
\text { (Second year at the } \\
\text { English } \\
\text { Department) }\end{array}$ & $\begin{array}{l}\text { Titigweti English Club } \\
\text { (Venue: University of Abomey-Calavi, } \\
\text { Benin) }\end{array}$ & Intermediate \\
\hline & Amèdé & Male & 27 & $\begin{array}{l}\text { Undergraduate } \\
\text { (Third year at the } \\
\text { English } \\
\text { Department) }\end{array}$ & $\begin{array}{l}\text { Lodestar English club } \\
\text { (Benin American Language Center of } \\
\text { Cotonou) }\end{array}$ & Post-Intermediate \\
\hline
\end{tabular}

\subsection{Validity and Reliability}

A panel of judges consisting of three academic University instructors and two secondary school instructors was asked to evaluate the validity of the questionnaire items used for the study. Moreover, the research questions and variables (Note 12) of interest (the listening in mute approach as dependent variables (Note 13) and the respondents' background information, opinions about the listening in mute approach as independent variables (Note 14)) came from the review of related literature to develop construct validity.

Many sources of evidence have been used in data collection, across half a year time period. The planning of interviews and focus groups such as the participants' identities which were kept anonymous for ethical reasons in this study were all cross-matched with the research questions and variables of interest. All that has been recorded and reported was checked to guarantee a precise representation of 
experiences of the respondents who were all orally informed in advance about the aims of the study before volunteering to engage in it. All the respondents for the interviews and focus groups were allowed to read and review the transcripts of their statements. As pointed out by Baxter and Jack (2008, p. 550) "(all) the evidence created (through the data collection of the present) case study design is considered robust and reliable".

\subsection{Procedures Used to Analyze the Data Collected from the Survey}

To analyze the data collected from the individual interviews and focus groups, inductive analysis strategy similar to the one used by researchers such as Bodgan and Biklen (1992) and Davis (1995) was also adopted. This approach focuses on the thorough description, analysis, and interpretation of data. It first deals with the coding of the data, their classification into a descriptive group and the identification of the points and traits that emanate from them and which define the respondents' perceptions, beliefs, points of views and attitudes. In this study, data were collected and analyzed simultaneously.

This simultaneous analysis procedure helped to determine the points and traits emanating from the data. It comprises the following five tasks: (1) first-cut analysis, (2) coding, (3) grouping, (4) determination of the correlations, (5) presentation of the traits (Freeman, 1998, pp. 82-119).

\section{Presentation, Analysis, and Interpretation of the Results}

\subsection{Interviews}

Freeman (1998, p. 216) describes interview as a "structured oral exchange with someone". Wang (2009) by referring to Duff and Yin $(2008,2009)$ points out that "it is an essential and commonly used source of case study evidence" (p. 76). According to Spradley (1979), an ethnographic interview is "a series of friendly conversations into which the researcher slowly introduces new elements to assist informants to respond as informants" (p. 58).

To probe the informants developing views about autonomous language learning through the listening in mute program, interviews have been used. The data collected through the different individual interviews are analyzed and presented in Table 2.

In sum, most of the respondents mentioned that the listening in mute program helped them to learn a considerable number of words and expressions within the half a year time period that the experiment has lasted. Each of them confessed that this approach enabled them to develop their listening and decoding skills. Some even mentioned that it made the English language look all of a sudden more familiar to them. Some others argued that it made easier English vocabulary learning and word pronunciation. They added that this program puts students in a learning situation that approximates the one of the native speakers or the one that enables a child to acquire a language instinctively. All of them pointed out that it enables the learner to remember words which she/he has heard and which she/he has never seen before in a written form.

These results suggest that the core center of this approach is the subconscious which operates simultaneously with the consciousness even though during sleep time, the latter looks inactive. This 
implies that there is a relationship between the subconscious and the process of language acquisition which occurs not only through the simultaneous action of the subconscious and the consciousness but more in the state of unconsciousness.

\subsection{Results of the Cross-Case Analysis}

One of the features of multiple case studies has to do with the fact that they enable to examine the differences and similarities that result from the analysis of individual cases. The cross-case analysis of the subjects' stated beliefs suggests the following two major trends as those that are consistent with their perceptions about the effectiveness of the listening in mute approach.

1) The first common opinion of the seven subjects regarding the effectiveness of the listening in mute approach relates to the development of the listening and decoding skills. All of them believed that this approach is a facilitative program that helped each of them to develop pronunciations skills. They argued that it makes easier English vocabulary learning and word pronunciation.

2) The second common opinion of the seven subjects regarding the effectiveness of the listening in mute approach relates to the fact that it puts the learner in a learning situation that is similar to the one of the child. All of them believed that through the action of the subconscious, it enables the learner to get a lot of words and expressions never seen by him/her before in a written form.

\subsection{Focus Groups}

One of the general principles to consider when designing a focus group is the number of participants per group which approximately ranges from 6 to 10 people, who share similar characteristics or common interests. However, as pointed out by Cohen and Crabtree (2006) when referring to Morgan (1996), "there may be reasons to have smaller or slightly larger groups" (para. 3). To get the views of each of the 7 respondents of the experiment about the listening in mute approach, they have been split into two groups. The first group consisted of 4 learners ( 2 males and 2 females), the second group was made up of 3 learners ( 2 males and 1 female).

\subsection{Responses to Focus Group Questions}

Of the six focus group questions that were asked to the EFL learners, only the responses provided to two of them by those participants are worth mentioning in the present research work.

1) To the question: "How can you describe the listening in mute approach?", most of the participants involved in each focus group pointed out that the listening in mute approach is a program that helps learners remember words and expressions they have heard once and which they have never seen before in a written form. Commenting on the positives of this program, some of them declared: "It is a program that may help the EFL learner overcome the hindrances to a normal speech by acquiring words, native accent, interjections, and expressions intuitively". "It puts learners in a learning situation that approximates the one of the native speakers or the one that enables a child to acquire a language instinctively".

2) To the question: "What kind of language skills have you improved through your participation in this experiment?", most of the subjects mentioned that they have improved their listening skills. Some 
added that they have developed decoding and pronunciation skills. They stated: "During reading activities, I succeed in decoding and pronouncing properly many difficult words now. Sometimes, I even have the impression of having already seen them before; which, in fact, is not the case".

\subsection{Summary of the Cross-Analysis of the Data Collected from the Two Focus Groups}

The cross-analysis of the data collected from the participants in each of the two focus groups suggests the following three major trends as those that were consistent with their perceptions about the effectiveness of the listening in mute approach.

1) The first common opinion of all the subjects from the two focus groups relates to the development of their listening and pronunciation skills. Most of them believed that the listening in mute approach has helped them enhance their ability to decode English words and expressions properly. Some mentioned that after their experienced this program, there are many words that sound from now on familiar to them; words or expressions that they have never seen before in a written form.

2) The second common opinion of those subjects relates to the fascinating way with which they could acquire their target language. They all believed that through the action of the subconscious, the listening in mute approach makes easier language vocabulary learning and word pronunciation.

3) The third common opinion expressed by those subjects relates to the development of their self-confidence. They all believed that the development of their decoding ability through the use of the listening in mute approach produced among them more autonomy or self-confidence. They mentioned that the fact that they could now decode more easily words and expressions used by a native speaker or any English speaker makes them feel more interested in their target language learning.

To summarize, in light of all the above, we can say that the experience of the listening in mute approach has effectively helped learners to develop their listening skills and other abilities such as the decoding and the pronunciation. This shows that this program helps in foreign language learning. It enables EFL learners to expand their knowledge in English.

Similarly, the analysis of the results obtained from individual interview questions as well as the one of those provided by the respondents to focus group questions revealed that there is a relationship between the subconscious and language acquisition process. They showed that through the action of the subconscious, the listening in mute approach enables the EFL learner to develop listening and decoding skills. This proves that the objective of the present study (see section 1 or section 1.1) has been met and that it supports the starting hypothesis of the study (see section 1.3). 
Table 2. Presentation and Analysis of the Data Collected through the Different Individual Interviews

\begin{tabular}{|c|c|c|c|c|}
\hline study & Background Information & $\begin{array}{l}\text { Description of the } \\
\text { Listening in mute approach }\end{array}$ & $\begin{array}{l}\text { Opinions about the Listening in mute } \\
\text { approach }\end{array}$ & Analysis and Interpretation \\
\hline $\mathrm{N}^{\circ} 1:$ & She was 21 years old and in first year at & She believes that the listening & She believes that the program helped her & The analysis of responses provided by the case \\
\hline \multirow[t]{14}{*}{ Aminata } & the English Department of the & in mute approach facilitates & to learn a considerable number of words & study $\mathrm{N}^{\circ} 1$ to open-ended and closed-ended \\
\hline & University of Abomey-Calavi in the & language learning and helps & within the half-year time period that has & questions during the interview session showed \\
\hline & Republic of Benin. To improve her & learners to develop their & lasted the experiment. She stated, & that the listening in mute approach has a \\
\hline & English language, she has decided to & listening skills. She regards this & "Thanks to this approach, I developed my & positive impact on her English language \\
\hline & join, two weeks before the experiment & program as being suitable for & listening skills and suddenly realized one & learning. They demonstrated that the low \\
\hline & of the Listening in mute approach, one & foreign language learners who & day, during the second month of the & volume listening approach has the ability of \\
\hline & of the English language Clubs of her & most of the time struggle to & experimentation that I could partly & developing the learner's listening and decoding \\
\hline & University (the Titigweti English Club). & learn new words which are & understand the news presented on the & skills through the action of the subconscious. \\
\hline & Before experiencing the low volume & difficult to pronounce and & BBC's radio channel". "This technique & These results suggest that there is a \\
\hline & listening approach, she was used to & memorize. She stated, "It & makes the English language look all of a & relationship between the subconscious and the \\
\hline & complaining of not having a good & enables the learner to & sudden more familiar to me". & process of language acquisition. \\
\hline & strategy to learn new words. & remember of words he has & & \\
\hline & & heard and which he has never & & \\
\hline & & seen before in written form". & & \\
\hline $\mathrm{N}^{\circ} 2:$ & He was 20 years old and in upper $6^{\text {th }}$ & He perceives the program as an & "This is a miracle approach," he said. He & The analysis of responses provided by the case \\
\hline \multirow[t]{16}{*}{ Dossou } & (Terminale in the French educational & approach that enables learners & further mentioned the following & study $\mathrm{N}^{\circ} 2$ to open-ended and closed-ended \\
\hline & system) at the General Educational & to practice a variety of skills & statement: & questions during the interview session after the \\
\hline & School of Godomey (CEG Godomey). & such as listening (words & It's strange what happened to me one day & six-month experiment on the listening in mute \\
\hline & Before he experienced the listening in & decoding) and pronunciation & while I was experiencing it. I, who could & approach revealed that this program has the \\
\hline & mute approach, he only had a three & (accent, intonation and words & not understand anything about what is & ability to help the leaner learn his target \\
\hline & weeks experience of language oriented & articulation). Commenting on & said on the BBC radio channel, suddenly & language intuitively. This suggests through an \\
\hline & Extracurricular Activities such as the & this aspect, he said: "The & realized, one day when I woke up, that I & action of the subconscious, the listening in \\
\hline & one of his school (the Afro-Dream & listening in mute program is a & could understand the majority of what & mute approach enables the learner to develop \\
\hline & English Language Club) in which he & very interesting approach and & was saying. It is to believe that during my & listening, decoding and pronunciation skills. \\
\hline & has decided to join so that to widen his & highly practical for foreign & sleep, something came to unbind my ears. & \\
\hline & knowledge in English. He has used in & language learning". & It is as if English was a language that I & \\
\hline & the past, many memorizing strategies in & "It is a program that may help & had always mastered. What surprised me & \\
\hline & vain. However, he remained optimistic & the EFL learner overcome the & most was that I could also decode the & \\
\hline & to this regard hoping to discover the & hindrances to a normal speech & interjections used by the speakers. & \\
\hline & best approach at the proper time. This & by acquiring words, native & & \\
\hline & explains his willingness to participate & accent, interjections, & & \\
\hline
\end{tabular}


in the survey.

$\mathrm{N}^{\circ} 3$ :

Cokou

\section{He was 18 years old and in lower $6^{\text {th }}$ (Première in the French educational} system) at College Martin Luther King of Cotonou, Benin. To improve his oral communication and listening skills, he has decided to join the English Community Oasis Club which is the only language oriented Extracurricular Activities of his school. He had always learned news words by heart and found this technique very irksome. Since he wanted to vary it with a new one, he volunteered to participate in this study. $\mathrm{He}$ also expected that this experimentation gives him the chance to discover a new self-learning technique that could help him improve his academic performance. She was 16 years old and in lower $6^{\text {th }}$ (Première in the French educational system) at the General Educational School of Godomey (CEG Godomey). Before she experienced the listening in mute approach, she only had a one week experience of language oriented Extracurricular Activities. Indeed, to improve her academic performance and develop her listening and speaking skills, she has decided to join the English Language Circle of her school (the Afro-Dream English Language Club). expressions intuitively".

He believes that the listening in mute approach is an effortless language learning technique that enables learners to develop their listening and pronunciation skills. He said: "it is a program that is designed to make EFL students learn their target language in a effort". "This approach may help EFL learners acquire the English language in the same way as native speakers". "It does not require the presence of a teacher and makes, therefore, foreign language learning comfortable".

She perceives the program as an approach that enables learners to develop listening (words decoding) and pronunciation skills. She stated, "The listening in mute approach is a self-learning technique that helps the EFL learner getting used to native speakers' accent and develop the ability to decode words or phrases used by a speaker". "It is an approach which enables to estimate the value or action of the subconscious in language learning". natural way without any

"This self-learning approach is fascinating," he said. He believes that it makes easier language vocabulary learning and word pronunciation. $\mathrm{He}$ stated, "Thanks to this approach, there are many words and expressions that I have never seen in written form before and which I can decode and pronounce easily now". "With the listening in mute technique, the learner does not have to make too much effort before acquiring her or his target language". "By adopting this strategy, the EFL learner will realize one day that he could speak English instinctively".

By referring to the impact of the listening in mute approach on her language skills, she pointed, "Based on my experience of the listening in mute approach I can confess that learning English in a foreign language setting is more than ever possible". "It is a program that helps EFL learners learning their target language intuitively". "Thanks to this program, I can decode more easily now the words and expressions used by a native speaker". $\mathrm{He}$ believes that the listening in
The analysis of the answers provided by the case study $\mathrm{N}^{\circ} 3$ to the open-ended and closed-ended questions asked to him during the interview session that follows the half-year time period experiment on the listening in mute approach showed that this program put the learner in a learning situation that is similar to the one of the child. It makes the learner's mind work as the one of a child. This suggests then that this low volume listening approach impacts positively on the learner through the action of the subconscious.

Based on the responses provided by the case study $\mathrm{N}^{\circ} 4$ to the questions posed to her during the interview session, it can be suggested that the listening in mute approach has a positive impact on language learning. Through the action of the subconscious, this program enables the EFL learner to develop listening and decoding skills

Based on the different responses provided by 


\begin{tabular}{|c|c|c|c|c|}
\hline \multirow[t]{12}{*}{ Codjovi } & (Terminale in the French educational & approach & helped him & the case study $\mathrm{N}^{\circ} 5$ to the open-ended and \\
\hline & system) at College Martin Luther King & outstanding program that & considerably his listening skills within & closed-ended questions posed to him during \\
\hline & of Cotonou, Benin. Since he did not & makes learners acquire & the half-year time period that has lasted & the interview session, it can be suggested that \\
\hline & have a good background knowledge in & language competence through & the experiment. He stated, "The soft & the soft listening approach helps the student \\
\hline & English, he has decided to join the & the action of their & listening approach really impacted on my & learn the language instinctively. Moreover, \\
\hline & English Community Oasis Club which & subconscious. $\mathrm{He}$ asserted, & listening ability. Thanks to it, there are & since it deals with the action of the \\
\hline & is the only language oriented & "this program puts students in a & many words that sound familiar to me & subconscious, it enables the learner to get a lot \\
\hline & Extracurricular Activities of his school. & learning situation that & from now on; words or expressions that I & of words and expressions never seen by this \\
\hline & He just has two weeks experience of & approximates the one of the & have never seen before in the written & one before in written form. \\
\hline & this out-of-classes' activity before & native speakers or the one that & form". & \\
\hline & participating in the present study. & enables a child to acquire a & & \\
\hline & & language instinctively". & & \\
\hline \multirow{21}{*}{$\begin{array}{l}\mathrm{N}^{\circ} 6: \\
\text { Dossi }\end{array}$} & She was 23 years old and in second & She believes that the listening & She believes that the program is an & The analysis of the answers provided by the \\
\hline & year at the English Department of the & in mute approach is really & original one. She stated: & case study $\mathrm{N}^{\circ} 6$ to the open-ended and \\
\hline & University of Abomey-Calavi in the & appropriate for foreign & Over time, I realized that there were a lot & closed-ended questions asked to her during the \\
\hline & Republic of Benin. To develop her & language learning. She pointed & of words I was able to decode even & interview session that follows the half-year \\
\hline & speaking and learning skills, she has & out that "it is an approach that & though there were many of them of which & time period experiment on the listening in mute \\
\hline & decided to join one of the English & makes the subconscious learn & I did not know the meaning. This often & approach has given extensive information. It \\
\hline & language Clubs of her University (the & the language instead of the & led me to refer to the dictionary in order & showed that the core center of the low volume \\
\hline & Titigweti English Club). She just has & learner and send later on the & to learn more about each of them. & listening approach is the subconscious which \\
\hline & one month and a half experience of this & knowledge acquired by the & However, there are many words that I did & operates simultaneously with the conscious \\
\hline & English-related Extracurricular Activity & subconscious to the conscious & not know before and which found & even though during sleep time, the latter looks \\
\hline & the time she was participating in this & of this one". "Through this & themselves overnight in my English & inactive. \\
\hline & study. Before taking part in the study, & learning process, there is a & vocabulary background. I confess that I & This suggests that language acquisition occurs \\
\hline & she was not able to decode or get the & reason to believe that the & have never seen them in written form & not only through the simultaneous action of the \\
\hline & meaning of the words and expressions & subconscious and the conscious & before. But surprisingly enough, I could & subconscious and the consciousness but more \\
\hline & used by her interlocutors or native & are used simultaneously". & understand their meaning. And all this & in the state of unconsciousness. \\
\hline & speakers such as the ones she could & "However, even if we realize & has been possible since the day I began to & \\
\hline & hear when listening to English radio & that during & experience this approach. & \\
\hline & channels. & subconscious has an ascendant & & \\
\hline & & on the conscious, those two & & \\
\hline & & phenomena & & \\
\hline & & simultaneously". & & \\
\hline $\mathrm{N}^{\circ} 7:$ & He was 27 years old and in the third & He believes that the listening in & By referring to the impact of the listening & Based on the responses provided by the case \\
\hline Amèdé & year at the English Department of the & approach & in mute approach on his English language & study $\mathrm{N}^{\circ} 7$ to the open-ended and closed-ended \\
\hline & University of Abomey-Calavi in the & well-structured program that & competence, he pointed: & questions posed to him during the interview \\
\hline
\end{tabular}




Republic of Benin. He only had one helps learners develop listening Based on my experience of this program, session, it can be suggested that the listening in
month experience of language oriented skill and widen their I can admit that it has developed my mute approach, a part from developing the
Extracurricular Activities (ECAs) and vocabulary background. He listening and decoding abilities. During learner's listening and decoding skills, makes
$\begin{aligned} & \text { to improve his English language, has asserted, "this program puts my reading activities, I succeed in the subconscious of this one acquire the } \\ & \text { decided to join one of them (the students in a learning situation pronouncing properly many difficult language instead of himslef. Once awake, the } \\ & \text { Titigweti English Club). } \\ & \text { which is similar to the one that } \quad \text { words now. Sometimes, I even have the information got by the subconscious of this } \\ & \text { his mother's tongue". }\end{aligned} \quad$ before. But where? I cannot say it.

\section{Discussion of the Results}

Second or foreign language learning is a task that is mainly dreaded by learners. The different problems experienced by them are related to the type of learning process they use. To be successful, second or foreign language learners should adopt the same process as that the child goes through when she/he acquires his/her first language. As argued by Haynes (2005), in her article "Language Acquisition vs. Language Learning", according to linguists, there is a considerable nuance between language acquisition and language learning. Whereas for them, the first one is "the product of a subconscious process very similar to the process children undergo when they acquire their first language" (Krashen, 1982, p. 10), the second one is "the product of formal instruction (that) comprises a conscious process which results in conscious knowledge 'about' the language, for example, knowledge of grammar rules" (Krashen, 1982; cited in Schütz, 2007).

Therefore, while some (Schmidt, 1990, 1995, 2001) consider that conscious understanding of the target language process is imperative if learners have to make correct forms and use them suitably, others such as Seliger (1983) and Lyons (1986) strongly assume that language learning is basically unconscious. Seliger claims that "obviously, it is at the unconscious level that language learning takes place" (Seliger, 1983, p. 187).

Similarly, as Seliger (1983), the linguist Stephen Krashen, in his theory of Acquisition-Learning, contends that "learning" is less important than "acquisition" (Krashen, 1982). He says that language is assimilated through an instinctive, automatic and subconscious way of which the learner need not be conscious (Krashen, 2003). Thus, by setting up the listening in mute (low volume listening or soft listening) approach developed in the present study, the researcher who supports the theory of Krashen (1982), expects to give EFL learners, the chance to acquire their target language in the same way as they assimilate their first language or mother tongue.

Indeed, the analysis of the responses provided by the participants in the present study to open-ended and close-ended questions asked to them through individual interviews and focus groups showed that the listening in mute approach is an effortless language learning technique that enables learners to develop their listening and pronunciation skills. By adopting this approach, learners develop their decoding skills. They succeed in figuring out as children "most words they have heard but have never 
seen in (a) written form... (They develop the ability to) sound out most words they are not familiar with at all..." (Oxford University Press ELT, 2012).

Comprehension $=$ Decoding Skills + Language Skills. So, by developing their decoding and listening skills, learners gain more understanding in their target language. The notion of decoding as discussed by Reading Horizons (2006-2017), is:

The process of translating print into speech by rapidly matching a letter or combination of letters (graphemes) to their sounds (phonemes) and recognizing the patterns that make syllables and words. There is an area in the brain that deals with language processing and does this process automatically. Unfortunately, about 30 percent of students do not access this part of their brain and therefore must be taught decoding strategies very explicitly and systematically (or be helped by an appropriate program). As far as listening is concerned, it is "the most essential skills needed by all of us and the hardest thing in the world" (Palit, 2013). According to the International Listening Association, "Listening is the process of receiving, constructing meaning from, and responding to spoken and/or non-verbal messages" (Cabrera, 2012). Johnson (1951) defines it as "the ability to understand and respond effectively to oral communication" (p. 58). Based on those definitions we can assert that hearing is not listening. As Davis (1977) observes, "Hearing is with the ears, but listening is with the mind" (p. 385). According to the Elmhurst College Learning Center cited in (Cabrera, 2012), "Hearing is the first stage of listening. (It) occurs when our ears pick up sound waves which are then transported to our brain. Listening is a communicative (or) active process...". Simply put, we listen with the mind and we hear with the senses (Cabrera, 2012). Listening is done through a conscious process whereas hearing is done through an unconscious process.

On the other hand, while "listening is to understand meaning only, without the need to translate; decoding is to translate or to understand meaning and importance" (Cabrera, 2012). We can then say that "Listening is an active process of eliciting information by decoding (translating) the code (and that) Hearing is a passive process of absorbing information" (Cabrera, 2012).

Tanway (2015) identifies five types of listening:

- Pseudo listening: Pretending to listen but not really absorbing anything from the conversation. Sometimes, the information we receive is something we just do not want to hear.

- The appreciative listening: Listening for pleasure and enjoyment, as when we listen to music, to a comedy or to an entertaining speech.

- The emphatic listening: Listening to provide emotional support for the speaker, as when a psychiatrist listens to a patient or when we lend a sympathetic ear to a friend.

- The comprehensive/active listening: Listening to understand the message of a speaker, as when we attend a classroom lecture or listen to directions for finding a friend's house.

- The critical/analytical listening: Listening to evaluate a message for purposes of accepting or rejecting it, as when we listen to the campaign speech of a political candidate or a salesperson.

Purani (2013) adds to these five types of listening three other ones which are as follows:

Published by SCHOLINK INC 
- Precision listening: Listening to single out one particular sound with exactness and clarity.

- Discriminative listening: Listening to distinguish between all the sounds in an environment

- Social listening: Listening with just enough effort to give a response.

Among these eight types of listening, the one in which the present study is particularly interested is the comprehensive or active listening. Once the learner has developed this ability, his/her speaking skill also emerges automatically. The opposite word of listening is talking. To become a good speaker we need to learn to listen. Listening is the first language ability we learn in our lives. It is thanks to it that we can acquire our first languages or mother tongues.

In summary, to command a second or foreign language, learners need to acquire it in the same way as they assimilate their first language. To help them succeed in this way, the listening in mute approach has been developed. By adopting this technique, they will realize over time that there are many words that they were able to decode even though the meaning of some of them sound unknown of them. This shows that there is a relationship between the subconscious and the process of language acquisition.

Learning a second or foreign language is not easy at all. Before getting a good command of a new language, the learner goes through many difficulties. One of them is the issue of decoding words and their meaning. They struggle to widen their vocabulary background because of the complexity of some of the words of their target language due to the multiplicity of their meanings. The learning by heart approach commonly adopted by those learners to learn new words has proved its limits among them. It was, therefore, necessary to think of setting up new techniques capable of overcoming these limits; new learning strategies through which the subconscious learning (genuine learning) could prevail over the language learning (conscious learning). Accordingly, the listening in mute approach has been elaborated. Through a series of experiments on seven intermediate EFL learners within half a year time period, to assess its effectiveness, this approach has proved to be very suitable for those learners. It has filled their expectations in terms of language acquisition. By listening to their radio turned on all night long on a channel broadcasting English-language programs while sleeping, learners at a given moment during this state enter in a form of hypnosis which allows them to acquire the language suitably.

Future researchers on language learning processes should attempt to explore other techniques that could help to better or supplement the listening in mute approach. They can also investigate with more details, the action of the subconscious during the process of language acquisition. Similarly, future research could include longitudinal studies to provide supportive evidence from the perceptions and beliefs of learners regarding the effects that their participation in the listening in mute programs have on their language acquisition. To help to generalize the findings of the present study, further research with a larger number of participants could also be considered.

Moreover, it would not be wise to close this research work without mentioning the limits in which it has been carried out and to give the definitions of some technical and standard words used in it. 


\section{Limitations to the Scope of the Study}

The study has two important limitations which are presented as follows:

- Due to the limited access to the participants, analysis was based only upon the participants' self-report assessment.

- Due to the small number of participants in the study and their particular learning situation, generalizability is limited.

\subsection{Definition of Few Terms}

The following are proceeded from Thanajaro (2000, pp. 7-8).

- English as a Foreign Language (EFL) refers to the role of English in countries where it is taught as a subject in schools but not used as a medium of instruction in education nor as a language of communication in the country (e.g., in government, or business).

- English as a Second Language (ESL) refers to the role of English for immigrant and other minority groups in English-speaking countries. These people may use their mother tongue at home or among friends, but use English at school and at work.

- First Language (L1) refers to a learner's mother tongue. This term is used synonymously with native language.

- Second Language (L2) refers to the language that is learned or acquired through training. In the present study, the second language is the English language.

- Suggestopedia refers to a teaching method developed by Lozanov. It makes use of music, visual images, and relaxation exercises to make learning more comfortable and effective.

- Target language refers to the language being learned. In this study, the target language is the English language.

Besides, as defined by Zounhin (2017, p. 19):

- English Language Clubs are learning crucibles where English is practiced effectively... There are learning places where learners can have the chance to have one-to-one or group discussions with their peers without experiencing too much anxiety...

\section{References}

Baxter, P., \& Jack, S. (2008). Qualitative case study methodology: Study design and implementation for novice researchers. The qualitative report, 13(4), 544-559.

Beaucamp, J. (2006). Pour une pratique consciente de l'oral au service du développement de la compétence de compréhension en ELVE. Spirales, 38.

Bodgan, R., \& Biklen, S. K. (1992). Qualitative research for education: An introduction to theory and methods (2nd ed.). Boston: Allyn and Bacon.

Cabrera, J. A. (2012). Decoding Skills-Listening. Retrieved March 26, 2017, from https://www.fr.slideshare.net/JaimeCabrera3/skills-decoding-listening?qid=1bc128bc-19d7-40c3-8 74b000f161a3a1b\&v=\&b=\& fromsearch $=1$ 
Carpenter, H. W. (2004). The Genie Within: Your Subconscious Mind-How it Works and how to Use it. Anaphase II Publishing.

Chmiliar, L. (2010). Multiple-case designs. Encyclopedia of case study research, 1-2.

Cohen, D., \& Crabtree, B. (2006). Qualitative Research Guidelines Project. Retrieved May 14, 2015, from http://www.qualres.org/HomeFocu-3647.html

Davis, K. (1977). Organizational behavior: A book of readings. McGraw-Hill Companies.

Davis, K. A. (1995). Qualitative theory and methods in Applied Linguistics research. TESOL Quarterly, 29(3), 427-453. https://doi.org/10.2307/3588070

Descartes, R. (1960). Discours de la méthode. CEuvres de Descartes, 6, 1964-1974.

Freeman, D. (1998). Doing teacher research: From inquiry to understanding. Boston: Heinle and Heinle Publishers.

Godin, C. (2004). Dictionnaire de philosophie. Fayard, coll. Aubin, Poitiers.

Gregg, K. R. (1984). Krashen's monitor and Occam's razor. Applied linguistics, 5, 79. https://doi.org/10.1093/applin/5.2.79

Haynes, J. (2005). Language Acquisition vs. Language Learning. Language Learning.

Haynes, J. (2005). Language Acquisition vs. Language Learning. Retrieved April 1, 2017, from http://www.everythingesl.net/inservices/language_acquisiti_vs_language02033.php

Jin, J. (2011). An evaluation of the role of consciousness in second language learning. International Journal of English Linguistics, 1(1), 126. https://doi.org/10.5539/ijel.v1n1p126

Johnson, K. O. (1951). The effect of classroom training upon listening comprehension. Journal of Communication, 1. https://doi.org/10.1111/j.1460-2466.1951.tb00103.x

Krashen, D. S. (1981). Second Language Acquisition and Second Language Learning. Oxford, Pergamon Press.

Krashen, S. (1982). Principales and practice in Second Language Acquisition. Oxford: Pergamon Press.

Krashen, S. (2003). Explorations in Language Acquisition and Use. Portsmouth: Heinemann.

Krashen, S. D. (1985). Applications of psycholinguistic research to the classroom. In C. James (Ed.). Practical applications of research in foreign language teaching (pp. 51-66). Lincolnwood, IL: National Textbook Co.

Krashen, S. D., \& Terrell, T. D. (1983). The natural approach: Language acquisition in the classroom.

Lefébure, F. (1988). Phosphénisme: La clé scientifique des manifestations surnaturelles: Lourdes et le phosphénisme. Ed. CDRPH.

Lozanov, G. (1979). Suggestology and suggestopedia: Theory and practice. United Nations Educational, Scientific, and Cultural Organization.

Lyons, W. (1986). The Disappearance of Introspection. Cambridge, Mass.: MIT Press.

McLeod, S. A. (2008). Independent, Dependent and Extraneous Variables. Retrieved November 17, 2015, from http://www.simplypsychology.org/variables.html 
Merriam, S. (1998). Qualitative research and case study applications in education (2nd ed.). San Francisco: Jossey-Bass Publishers.

Miles, M., \& Huberman, A. (1994). Qualitative data analysis: An expanded sourcebook (2nd ed.). Thousand Oaks, CA: Sage.

Morgan, D. L. (1988). Focus groups as qualitative research. Newbury Park, Calif: Sage. Publications.

Oxford University Press ELT. (2012). Decoding skills: A neglected part of listening comprehension? Retrieved March 28 , 2017, from https://www.oupeltglobalblog.com/2012/05/17/decoding-skills-a-neglected-part-of-listening-comp rehension/

Palit, N. G. (2013). Listening skills. Formation, technologie, Business. Retrieved March 26, 2017, from https://www.fr.slideshare.net/nandapalit/listening-skills-1-23984964?qid=c2ab06fdd859-4bae-a18 $3-689 \mathrm{cc} 81 \mathrm{c} 34 \mathrm{~b} 2 \& \mathrm{v}=\& \mathrm{~b}=\&$ from_search $=1$

Poursin, G. (2008). La luminopédagogie. Retrieved March 24, 2017, from http://www.dailymotion.com/video/x6yjzw_la-luminopedagogie_school

Purani, R. (2013). 7 types of listening. Electronics and Communications engineering at GCET IEEE Student Branch. Formation, Actualités \& Politique, Technologie. Retrieved March 30, 2017, from https://www.fr.slideshare.net/Rhythmm FeelDMusik/7-types-of-listening?next_slideshow=2

Reading Horizons. (2006-2017). Reading Strategies: What is Decoding? Retrieved March 25, 2017, from http://www.readinghorizons.com/reading-strategies/decoding/what-is-decoding

Schmidt, R. (1990). The role of consciousness in second language learning. Applied Linguistics, 11, 129-158. https://doi.org/10.1093/applin/11.2.129

Schmidt, R. (1995). Consciousness and foreign language learning: A tutorial on the role of attention and awareness in learning. Attention and awareness in foreign language learning, 9, 1-63.

Schmidt, R. (2001). Attention. In P. Robinson (Ed.), Cognition and second language instruction (pp. 3-32). Cambridge: Cambridge University Press.

Schütz, R. (2007). Stephen Krashen's theory of second language acquisition. English made in Brasil, 2(2).

Seliger, H. W. (1983). Learner interaction in the classroom and its effect on language acquisition. Classroom oriented research in second language acquisition, 246-267.

Spradley, J. (1979). The Ethnographic Interview. NY: Holt, Rinehart, and Winston.

Tanway, S. (2015). Listening and its Types. Communication Skills. Education. Division L (I.C). $\begin{array}{llll}\text { Retrieved } & \text { March } & \text { 29, } & \text { from }\end{array}$ https://www.slideshare.net/tanmay98/listening-55163091?qid=d957d303-f7e3-40e2-ad8d-4554d1 $55 \mathrm{c} 77 \mathrm{c} \& \mathrm{v}=\& \mathrm{~b}=\&$ from_search $=2$

Thanajaro, M. (2000). Using authentic materials to develop listening comprehension in the English as a second language classroom (Doctoral dissertation). Virginia Polytechnic Institute, State University. 
Wang, Y. C. (2009). Anxiety in English language learning: A case study of Taiwanese university students on a study abroad programme (Published doctoral dissertation). University of Leeds.

Yin, R. K. (2003). Case study research: Design and methods (3rd ed.). Thousand Oaks, CA: Sage.

Zounhin, T. C. M. (2017). English Learning Circles: An Innovative Way to Foster Oral Communication among EFL Learners. International Journal on Studies in English Language and Literature (IJSELL), 5(3), 19-40.

\section{Notes}

Note 1. Since the term "mute" is often confusing, it is noteworthy to clarify its meaning in the present article. Therefore, in this document, it does not mean dumb, speechless or not able to give out sound but soften, muffle. It refers to the word "sourdine" which etymologically originates from the Italian word "sordina" between 1670 and 1680. Simply put, in this paper, the word "mute" means to reduce the intensity of a sound, to deaden or muffle a sound, to lower the volume of an electronic device such as a radio set.

Note 2. In this paper, the pronouns $(\mathbf{H i s}),(\mathbf{H i m}),(\mathbf{H e})$ are sometimes used as neutral to address simultaneously the two genders (male and female).

Note 3. English Language Clubs which "are learning crucibles where English is practiced effectively..." (Zounhin, 2017, p. 19).

Note 4. "Part of the mind which operates below the level of consciousness; mental processes occurring outside of an individual's awareness" (Dict Box, 2015). Dict Box (V11.8.1) is an English to French \& French to English offline Dictionary \& Translator, developed by Xung Le. For more details please Cf. http://www.dictionarybox.com

Note 5. More or less clear intuition of an individual to his mental state, his life and the world that surrounds him (Adapted from Descartes, 1937 reviewed in 1960).

Note 6. 'L'ELVE (Enseignement d'une Langue Vivante Etrangère à l'Ecole) accorde une place de choix aux compétences relevant du code oral et à la compréhension en particulier...” (Beaucamp, 2006, p. 53).

Note 7. André Comte-Sponville (2001). Dictionnaire de philosophie. PUF, 2001.

Note 8. Universal Declaration of Human Rights (Article 1) that was adopted on December 10, 1948, by the General Assembly of the United Nations.

Note 9. "The immediate or mediate internalized relationship that a human being can establish with the world where he lives or with himself" (Adapted from Christian Godin, 2004).

Note 10. "The mental capacity to make moral value judgments...on acts done by oneself or by others" (Ibid).

Note 11. Carole Fortin (n.d). Le fonctionnement du subconscient. Aide Psycholiqique Rive-Sud. $\begin{array}{llll}\text { Retrieved July } & 25, & \text { 2016, }\end{array}$ http://www.aidepsychologique.com/articles/le-fonctionnement-du-subconscient/ 
Note 12. According to McLeod (2008, para.1 and 2), "A variable is anything that can vary, i.e., change or be changed, such as memory, attention, and time are taken to perform a task, etc.".

Note 13. "Dependent Variables are variables the experimenter measures, after making changes to the Independent variable that are assumed to affect the Dependent Variables" (McLeod, 2008, para. 1 and 2).

Note 14. "Independent Variables are variables the experimenter manipulates (i.e., changes)—assumed to have a direct effect on the Dependent Variable" (Ibid).

\section{Appendix A}

\section{Interview Questionnaire Guide}

The same process and set of questions were used to interview all candidates.

1. Background Information Review

Name:

Gender:

Age:

Proficiency level in English:

2. Introduction and Purpose Of The Interview

1) Introduction

Good morning/afternoon ... (Name of the Interviewee). My name is ... Thank you for volunteering for this interview session.

2) Purpose of the interview

We are here today to talk about your perception about the listening in mute approach since you just experienced for a half-year period time. Although you have already been submitted to the completion of a questionnaire form to this regard, it is also crucial to gather additional information from you through one-to-one discussion. Therefore, the opportunity is given to you to support or change your mind regarding your first opinions about this experience. Simply put, the purpose of this interview session is to get your perceptions about the way this experience has impacted on your English learning. Thus, my objective is not to give you my opinion or share information with you. All that matters is your impressions. You will not be allowed to answer by Yes/No and Right/Wrong. However, you have the right to change your mind. Please feel comfortable to speak your mind.

3. Guiding or Exploration Questions

1) What do you think about the listening in mute approach?

2) How can you describe the listening in mute program?

3) What are the positive aspects of this program?

4) What kind of language skills have you improved through your experience of this approach?

5) What do you prefer or dislike about this self-learning approach?

6) Provide any other comments.
Language skill to improve:

Reason for studying English:

Length of time of English learning:

Published by SCHOLINK 


\section{Conclusion}

Thank you very much for your cooperation. Your comments have been very helpful.

\section{Appendix B}

\section{Focus Group Questionnaire Guide}

1. Introduction, Purpose, and Warning for the Focus Group

Hello, everyone! Glad to know that you have all volunteered to participate in this focus group. I know that you are all busy and give thanks for your time.

My name is ... and the one next to me is my colleague...

The objective of the present group discussion is to evaluate your perceptions and beliefs about the impact of the listening in mute program on your English language learning. It is true that you have already been submitted to the completion of a questionnaire form to this regard at the end of your six months' time experimentation on the program. It is also true that you have all been interviewed individually about that. However, your help is still required to gather more information about the real effect of this educational program on your English language acquisition. This group discussion will not last more than two hours.

Now may I audio-taped the discussion to make its retrospection easy? I ensure you that what you will be saying here will be kept secret till they are transcribed literally and destroyed.

Please note that you will not be allowed to answer by Yes/No and Right/Wrong. However, you have the right to change your mind. Please feel comfortable to speak your mind. There will be no particular order to have the floor. Just make sure that only one person speaks at a time. When you feel like saying something, please just go ahead! In addition, you do not need to share the same point of view with the other members of the group.

Does anyone have anything to say before we start? (If yes, please do!) If not, then I will ask my colleague to switch on the recorder.

\section{Warming Up or Engagement Questions}

First and foremost I would like everyone to introduce themselves. Introduce yourself to your neighbor and ask about her/his name, dream country, and hobbies. Now I will be giving you two minutes to remember your best achievement in English-learning since the time you have been introduced to the listening in mute approach (Something that you were not able to do in English and that you have succeeded in doing).Is there anyone ready to share her or his story?

\section{Guiding Questions}

1) How can you describe the listening in mute approach?

2) How do you feel today regarding your English language learning?

3) What kind of English language skills have you improved through your experience on the listening in mute approach?

4) What do you prefer or dislike the most about the listening in mute program? 
5) What kind of strategy did you usually use before you experience, the listening in mute approach??

6) In addition to all we have been discussing so far, what else would you like to say in regard to your listening in mute's experience?

4. Conclusion

Thanks a lot for taking part in successful focus groups. Your views will be very useful for the study.

The same process and set of questions were used for all the four focus groups. 